\title{
The Role of Jordanian Universities in Promoting Citizenship Values among Students
}

\author{
Tahany Fawzy Ahmad Al-Gassem
}

\begin{abstract}
The researcher of this study aimed to explore the role of Jordanian universities in promoting citizenship values among students. She aimed to explore the degree to which Jordanian universities promote citizenship values among students. To be more specific, she aimed to explore the degree to which (the faculty members, student activities and curricula) in Jordanian universities promote citizenship values among students. She adopted a descriptive analytical approach. She developed a questionnaire. She selected a random stratified sample. She selected the sample from the faculty of educational sciences at 4 universities in Jordan (i.e. the University of Jordan, the Hashemite University, Yarmouk University and Mu'tah University). The sample consists from 950 female and male BA students through electronic means. Questionnaire forms were passed to the members of the sample. 923 forms were retrieved. The response rate is $97.15 \%$. Due to having missing data, 4 forms were excluded. Thus, the final sample consists from 919 students. The researcher found that the degree to which Jordanian universities promote citizenship values among students is high in all the areas jointly and separately. She recommends providing faculty members in Jordanian universities with training courses about the significance of promoting citizenship values among students.
\end{abstract}

Keywords: Jordanian universities, citizenship values, students, Jordan

DOI: $10.7176 / \mathrm{JEP} / 11-33-08$

Publication date: November $30^{\text {th }} 2020$

\section{Introduction}

Today, universities are responsible for meeting three main functions. Those three functions are represented in delivering university education, conducting scientific research and serving the society. Through doing such functions, universities aim at providing the societies with skilful and informative human resources who develop the society in social, political and economic areas. They also aim at developing the students' personalities and promoting awareness among them (Al-Asali and Suwaidan, 2017).

In other words, the goals of universities aren't limited to providing the society with graduates in various majors. In fact, universities aim at providing students with social, psychological and educational care rather than academic care only. They aim at developing students' talents and unleashing students' potentials. They aim at developing the students' personalities, ideologies and behaviours. They aim at meeting such goals in the aim of providing the society with good citizens who love their homeland and desire to develop and defend it (Al-Shaqran (2016).

In order for universities to provide the society with good and loyal citizens, universities seek promoting citizenship values among students and delivering effective citizenship education. Citizenship education aims at promoting citizenship values among students. It aims at letting students engage in social and political activities in their homeland and promoting knowledge about national issues (Danju \& Uzunboylu, 2016). It aims at improving the relationship and bonds between one and his/her homeland. It can be provided through (faculty members, student activities and curricula) (Al-Asali and Suwaidan, 2017).

Citizenship education aims at engaging students in the elections and letting them identify their political rights and exercise them. It aims at promoting letting citizens love and admire their homeland and express their political views freely. It aims at providing the society with citizens who are productive and contribute to the development of the society. It aims at encouraging citizens to refrain from committing deviant acts and crimes. It encourages citizens to show a high compliance with the laws, and code of ethics. It shall reduce the crime rate in society (AlAwamrah and Al-Zboon, 2013).

Due to the significance of promoting citizenship values and delivering citizenship education, the researcher of the present study believes that it's necessary to conduct studies about such issues. Thus, she aimed to explore the role of Jordanian universities in promoting citizenship values among students. She aimed to explore the degree to which Jordanian universities promote citizenship values among students.

\section{Objectives:}

The Main Objective:

-The researcher aimed to explore the degree to which Jordanian universities promote citizenship values among students.

-Sub-objectives:

To be more specific, the researcher aimed to 
1)-Identify the degree to which the faculty members in Jordanian universities promote citizenship values among students.

2)-Identify the degree to which student activities in Jordanian universities promote citizenship values among students.

3)-Identify the degree to which curricula in Jordanian universities promote citizenship values among students.

\section{Questions}

-Main Question:

The researcher aimed to answer the following question: (To what degree do Jordanian universities promote citizenship values among students?)

-Sub-questions:

To be more specific, the researcher aimed to answer the following questions:

Q.1. To what degree do the faculty members in Jordanian universities promote citizenship values among students?

Q.2. To what degree do student activities in Jordanian universities promote citizenship values among students?

Q.3. To what degree do curricula in Jordanian universities promote citizenship values among students?

\section{The Study's Significance}

The present study is significant due to the following reasons:

-The present study provides developers of university curricula in Jordan with information about the shortcomings in their curricula. Such information shall contribute to developing such curricula

-The present study provides educational leaders in Jordanian universities with information about the role of faculty members in promoting citizenship values. That shall enable educational leaders to identify the training needs of faculty members in this regard.

-The present study provides researchers with an original instrument for conducting similar studies in schools, teacher colleges and other countries.

\section{The Study's Limits}

Spatial limits: This study was conducted in four Jordanian universities (i.e. University of Jordan, the Hashemite University, Yarmouk University and Mu'tah University).

Temporal limits: This study was conducted during the first semester of the academic year (2020/2021).

\section{Definition of Terms:}

\subsection{Theoretical definitions:}

-Citizenship: It involves the degree to which people are aware of their rights and responsibilities (Lister, 1998). It is represented in the relationship and bonds between one and his/her homeland (Al-Asali and Suwaidan, 2017). -Citizenship education: It refers to using teaching strategies in the aim of letting students acquire democratic thinking methods which foster informed and active citizenship (Hoge, 2002). It involves holding discussions about political issues, such as: elections and voting (Westheimer and Kahne, 2004). It aims at promoting knowledge about national issues an addressing them in order for students to engage in social and political activities in their country (Danju \& Uzunboylu, 2016)

\subsection{Operational definition}

-Citizenship education: The education that is delivered by Jordanian universities in the aim of promoting citizenship values among students. It is delivered through faculty members, curricula and students activities.

\section{Theoretical framework}

All educational institutions in society seek delivering citizenship education and promoting citizenship values among students. Citizenship education aims at providing citizens with knowledge about political issues. It aims at increasing the citizens' interests in politics and political activities (Verba et al., 1995). It aims at promoting interests in public affairs (Putnam, 1995). It aims at developing the social and human capital in society. It seek establishing a society which members are highly engaged in civic areas (Nie et al., 1996). It seeks developing the social skills of citizens and instilling positive humanitarian values within them. It encourages citizens to show good and productive behaviours and handle responsibilities in social and moral responsibilities. It contributes to increasing people's political literacy (Scott, and Lawson, 2002)

Citizenship education aims at promoting awareness about the significance and meaning of liberty, and equality. It aims at providing people with knowledge about their rights and duties as citizens. Such rights include: political, civil and social rights. Social rights include: one's right to get education. Political rights include: one's right to vote and get elected. Civil rights include one's right to get a fair trial (McCowan, 2009). Citizenship education provides citizens with knowledge about democracy and increases their civic engagement. It educates 
citizens in the aim of letting them become competent and responsible citizens. However, delivering effective citizenship education requires developing curricula and carrying out activities that aim at promoting citizenship values (Lin, 2013).

Citizenship values can be promoted through various means. For instance, they can be promoted through student activities. Student activities must encourage students to express their views, beliefs and opinions freely about national issues in accordance with the applicable laws. They must contribute to the development of students' national identity. They must encourage students to attend the celebrations of national events in order to develop their national identity. They must encourage students to defend homeland from any threat or attacker at any situation. That shall motivate students to join the military institutions and security agencies regardless of the financial gain. It shall motivate students to protect their homeland from any occupier or cultural threat (Jbarah, 2018).

Citizenship values can be promoted through curricula. For instance, curricula should promote loyalty, and belonging to homeland and democracy. They should promote knowledge among citizens about their roles, rights and duties as citizens. They should encourage students to show obedience to the ruler and the government of their homeland. They should encourage students to defend their homeland and fight against the spread of bad rumours about their homeland. They should instil good values within citizens and encourage them to comply with the customs and traditions of their homeland (Al-Jaser, 2019)

Citizenship education aims at increasing citizens' knowledge about legislations, history and laws of homeland It seek instilling ethics, values, \& morals within citizens. Such values include: courage, honesty, fairness, integrity and etc... Citizenship education aims at letting citizens acquire the skills and knowledge that are needed to engage effectively in the process of making decisions in society. It aims at developing citizens to become capable of making knowledge-based civic decisions that meet the interests of the public. Through delivering effective citizenship education, the bonds between the citizen and her/his homeland shall become better and stronger (Shin and Bednarz, 2019).

\section{Empirical Studies}

Al-Khawaldeh (2013) aimed to explore the degree to which the faculty members in Jordanian universities promote citizenship values among students. To be specific, he aimed explore the degree to which the faculty members promote political awareness, loyalty \& belonging to homeland, tolerance and respect for different people, group work-related values. He used a questionnaire. He selected a random stratified sample that consists from 928 female and male students. He used the SPSS program. Several results were found. For instance, the degree to which the faculty members in Jordanian universities promote citizenship values among students is moderate in all the areas jointly and separately. Faculty members promote knowledge about well-known figures who defended the country and sacrificed their lives. They encourage students to maintain public facilities and properties. They encourage students to hold on to their customs and national principles (Al-Khawaldeh, 2013)

The latter researcher reached other results. For instance, faculty members play a moderate role in promoting positive attitudes towards local products and developing students' national and cultural identities. They play a moderate in promoting compliance with laws and awareness about their duties and rights as citizens. They play a moderate in promoting awareness about the role of civil society institutions in the serving society and the role of the laws in promoting security. They play a moderate role in encouraging students to fight against violence and intolerance. They play a moderate role in encouraging students to respect different opinions and the ones who belong to other religions. They play a moderate role in promoting awareness about the role of the government in promoting peace and the way of addressing the cultural risks derived from the web. They play a moderate role in promoting equality, and justice (Al-Khawaldeh, 2013)

Al-Shaqran (2016) aimed to explore the role of student activities in promoting citizenship values among students in Umm Al Qura University. To be specific, he aimed to explore the role of student activities in promoting national belonging, proudness with homeland, and community participation. They used a questionnaire. The sample consists from 224 students enrolled in Umm Al Qura University. Those students were selected randomly. It was found that student activities play a moderate role in promoting citizenship values among students in Umm Al Qura University. That applies to all the dimensions jointly and separately. For instance, student activities play a moderate role in encouraging students to defend their homeland and participate in national events and celebrations. They play a moderate in developing students' national identity. They play a play a moderate role in promoting knowledge about the history of establishing the state (Al-Shaqran, 2016)

The latter researcher reached other results. For instance, student activities play a play a moderate role in promoting awareness about the role of civil society institutions in achieving social development. They play a play a moderate role in encouraging students to engage in voluntarily works and show compliance with laws. They play a play a moderate role in preserving the customs and encouraging students to participate in social development programs. They play a play a moderate role in promoting social solidarity. They play a play a moderate role in promoting knowledge about the government's effort in providing international rescue, and care for disabled people. 
They play a play a moderate role in promoting knowledge about the government's social and economic achievements and the government's effort in addressing Muslims-related issues. They play a moderate role in fighting against violence and discrimination (Al-Shaqran, 2016)

Al-Asali and Suwaidan (2017) aimed to explore the degree to which Palestinian universities promote citizenship values among students. To be specific, they aimed to explore the degree to which (the faculty members, student activities and curricula) promote citizenship values among students. They used a survey to collect data from 568 students. Those students were selected through the random stratified sampling method. They were selected from A- Istiqlal University and Najah University. It was found that the degree to which Palestinian universities promote citizenship values among students is high. That applies to all the areas jointly and separately. For instance, curricula encourage students to express their opinions freely and promotes a culture of respectful dialogue among students. They encourage students to hold on to their rights and exercise them. They promote democracy, loyalty, and sense of belonging. They promote knowledge about their constitutional rights, obligations towards their homeland. They develop students' national identity. They promote awareness about the significance of civil society institutions in society. They encourage students to address the problems faced by society (Al-Asali and Suwaidan, 2017).

The latter researcher reached other results. For instance, faculty members promote tolerance, belonging and loyalty. They encourage students to participate in political activities in society. As for the student activities, they contribute to address the problems faced by society. They promote belonging and loyalty and encourage students to participate in political activities in society. They promote awareness about the significance of voluntarily works. They seek promoting cooperation in the aim of developing the society (Al-Asali and Suwaidan, 2017).

Al-Zboun et al. (2020) aimed to explore the degree to which the national culture curriculum promotes citizenship values in the University of Jordan in Jordan. They used a questionnaire. They adopted a descriptive analytical approach. The sample consists from 745 students who were selected through the purposive sampling method. Those students were selected from the University of Jordan. Several findings were concluded. For instance, the degree to which the national culture curriculum promotes citizenship values in the University of Jordan is high. This curriculum plays a major role in promoting democracy, tolerance, equality, freedom and justice. It promotes respect for customs and traditions and knowledge about the government's achievements. It encourage students to maintaining national security and co-exist with others regardless of their race, colour or religion. It promotes awareness about the significance of global peace. It promotes love for the homeland and the government. It plays a moderate role in encouraging students to engage in voluntarily works and national events and celebrations.

Alwaely \& Alkhazalehb (2020) aimed to explore the role of faculty members in the Hashemite University in promoting citizenship values among students. They aimed to explore that in terms of (global peace, democracy, environmental education and human rights). They used a questionnaire for collecting data. The sample consists from 850 female and male students enrolled at this university. Several results were found. For instance, faculty members in the Hashemite University play a moderate role in promoting citizenship values among students in all the areas jointly and separately. They play a moderate role in training students about the way of managing and resolving conflicts. They play a moderate role in encouraging students to fight against intolerance, racism and discrimination. They play a moderate in encouraging students to express their opinions freely and show respect for human rights and freedoms. They play a moderate in encouraging students to engage in voluntarily works, do their duties as citizens and comply with law. They play a moderate role in promoting awareness about their rights and encouraging students to avoid making violation for human rights.

\section{Methodology}

9.1. Approach

The researcher adopted a descriptive analytical approach.

\subsection{Sample and Population}

The population consists from all the students who are enrolled in Jordanian universities. The researcher selected a random stratified sample. She selected the sample from the faculty of educational sciences at 4 universities in Jordan (i.e. the University of Jordan, the Hashemite University, Yarmouk University and Mu'tah University). The sample consists from 950 female and male BA students through electronic means. Questionnaire forms were passed to the members of the sample. 923 forms were retrieved. The response rate is $97.15 \%$. Due to having missing data, 4 forms were excluded. Thus, the final sample consists from 919 students. Table (1) presents data about the sample 
Table (1): Distribution of the sample in accordance with gender and university

\begin{tabular}{|l|l|l|l|}
\hline Variable & Category & Frequency & Percentage $\%$ \\
\hline \multirow{3}{*}{ Unender } & Male & 402 & 43.74 \\
\cline { 2 - 4 } & Female & 517 & 56.25 \\
\hline & The University of Jordan & 227 & 24.70 \\
\cline { 2 - 4 } & The Hashemite University & 225 & 24.48 \\
\cline { 2 - 4 } & Yarmouk University & 226 & 24.59 \\
\cline { 2 - 4 } & Mu'tah University & 241 & 26.22 \\
\hline
\end{tabular}

$\mathrm{N}=919$

\subsection{Instrument}

The researcher developed a questionnaire. She used a five point Likert scale that consists from the following rating categories: (strongly agree, agree, neutral, disagree and strongly disagree). The questionnaire consists from a cover page and three parts. The cover page presents the title of the research and name of the researcher. It collects data about gender and name of the university. The first part of the questionnaire collects data about the degree to which the faculty members promote citizenship values among students. It consists from 10 items. It was developed based on the studies conducted by Al-Khawaldeh (2013), Al-Asali and Suwaidan (2017), and Alwaely \& Alkhazalehb (2020).

The second part of the questionnaire collects data about the degree to which the student activities promote citizenship values among students. It consists from 12 items. It was developed based on the studies conducted by Al-Shaqran (2016) and Al-Asali and Suwaidan (2017). The third part of the questionnaire collects data about the degree to which the university curricula promote citizenship values among students. It consists from 12 items. It was developed based on the studies conducted Al-Zboun et al. (2020) and Al-Asali and Suwaidan (2017).

\subsection{Validity of the Instrument}

The initial version of the questionnaire was passed to two instructors. Those instructors work at a well-known Jordanian university and specialized in the field of education. Those instructors are PhD holders. They were asked to assess the instrument. They added that the questionnaire is clear and capable of meeting the intended goals. They added that there isn't any need for making any change or deletion in the questionnaire. The questionnaire was passed in Arabic language to the members of the sample and the two instructors. Then, it was translated into English language to be displayed in the published version of the study.

\subsection{Reliability of the Instrument}

The Cronbach alpha values are calculated for each area. They are displayed in the table shown below:

Table (2): Cronbach alpha values

\begin{tabular}{|l|l|l|}
\hline No. & Area & Cronbach alpha \\
\hline 1. & The degree to which the faculty members promote citizenship values among students & 0.72 \\
\hline 2. & The degree to which the student activities promote citizenship values among students & 0.79 \\
\hline 3. & $\begin{array}{l}\text { The degree to which the university curricula promote citizenship values among } \\
\text { students }\end{array}$ & 0.75 \\
\hline & Overall & 0.753 \\
\hline
\end{tabular}

All the values in the table above indicate that the questionnaire is reliable, because they are greater than 0.70 as it's suggested by Salehi \& Farhang (2019).

\subsection{Statistical analysis}

To analyse the data collected through the instrument, the researcher used SPSS program. She also calculated standard deviations along with means. She calculated frequencies, percentages and Cronbach alpha coefficient. She classified the means in accordance with specific criteria. Such criteria are displayed below:

Table (3): The criteria that are used by the researcher for classifying means

\begin{tabular}{|l|l|l|}
\hline Range & Level & Attitude \\
\hline 2.33 or less & Low & Negative \\
\hline $2.34-3.66$ & Moderate & Neutral \\
\hline 3.67 or more & High & Positive \\
\hline
\end{tabular}

*Source: Al-Amery (2020)

Regarding the five point Likert scale, it consists from five (5) rating categories that are shown below. 
Table (4): The categories and scores of the five point Likert scale

\begin{tabular}{|l|l|l|l|l|l|}
\hline Category & $\begin{array}{l}\text { Strongly } \\
\text { agree }\end{array}$ & Agree & Moderate & Disagree & $\begin{array}{l}\text { Strongly } \\
\text { disagree }\end{array}$ \\
\hline The score it represents & 5 & 4 & 3 & 2 & 1 \\
\hline
\end{tabular}

\section{Results and Discussion}

10.1. Results and Discussion related to the main question:

To what degree do Jordanian universities promote citizenship values among students?

To have the main question answered, the researcher calculated the mean of each area. She also calculated the overall mean for all the study's areas jointly. Those means are shown through table (5).

Table (5): The mean of each area of the study's areas

\begin{tabular}{|l|l|l|l|l|l|}
\hline No. & Area & Mean & Std. & Level & Rank \\
\hline 1. & $\begin{array}{l}\text { The degree to which the faculty members promote citizenship values } \\
\text { among students }\end{array}$ & 4.096 & 0.366 & High & 2 \\
\hline 2. & $\begin{array}{l}\text { The degree to which the student activities promote citizenship values } \\
\text { among students }\end{array}$ & 3.972 & 0.492 & High & 3 \\
\hline 3. & $\begin{array}{l}\text { The degree to which the university curricula promote citizenship values } \\
\text { among students }\end{array}$ & 4.240 & 0.496 & High & 1 \\
\hline & Overall & 4.102 & .0451 & High & \\
\hline
\end{tabular}

Based on table (5), the degree to which Jordanian universities promote citizenship values among students is high in all the areas jointly and separately. That is because the overall mean is 4.102 . The latter result is in agreement with the results concluded by Al-Asali and Suwaidan (2017). It indicates that higher education institutions significantly contribute to the promotion of citizenship values. It indicates that the educational policies of the latter institutions provide much attention to the promotion of citizenship values.

The mean of (the degree to which the university curricula promote citizenship values among students) is 4.240. It is high and ranked first. The mean of (the degree to which the faculty members promote citizenship values among students) is high and ranked second. The mean of (the degree to which the student activities promote citizenship values among students) is high and ranked third. The latter results are in agreement with the results concluded by (Al-Asali and Suwaidan (2017).

\subsection{Results and Discussion related to the first question:}

Q.1. To what degree do the faculty members in Jordanian universities promote citizenship values among students? Table (6): The degree to which the faculty members in Jordanian universities promote citizenship values among students

\begin{tabular}{|l|l|l|l|l|l|}
\hline No. & Statement & Mean & Std. & Level & Rank \\
\hline 1. & $\begin{array}{l}\text { Faculty members encourage students to maintain public facilities } \\
\text { and properties }\end{array}$ & 4.17 & 0.63 & High & 8 \\
\hline 2. & $\begin{array}{l}\text { Faculty members promote knowledge about well-known figures } \\
\text { who defended the country and sacrificed their lives }\end{array}$ & 4.63 & 0.18 & High & 2 \\
\hline 3. & $\begin{array}{l}\text { Faculty members encourage students to hold on to their customs and } \\
\text { traditions }\end{array}$ & 4.52 & 0.52 & High & 3 \\
\hline 4. & Faculty members promote positive attitudes towards local products & 4.24 & 0.34 & High & 6 \\
\hline 5. & $\begin{array}{l}\text { Faculty members promote awareness about the role of the } \\
\text { government in promoting peace }\end{array}$ & 2.10 & 0.27 & Low & 10 \\
\hline 6. & Faculty members encourage students to comply with laws & 4.73 & 0.15 & High & 1 \\
\hline 7. & $\begin{array}{l}\text { Faculty members promote awareness among students about their } \\
\text { duties and rights as citizens }\end{array}$ & 3.59 & 0.32 & Moderate & 9 \\
\hline 8. & $\begin{array}{l}\text { Faculty members promote awareness among students about the role } \\
\text { of civil society institutions in the serving society }\end{array}$ & 4.21 & 0.50 & High & 7 \\
\hline 9. & Faculty members promote loyalty and belonging to homeland & 4.36 & 0.27 & High & 5 \\
\hline 10. & Faculty members encourage students to engage in voluntarily works & 4.41 & 0.48 & High & 4 \\
\hline & Overall & 4.096 & 0.366 & High & \\
\hline
\end{tabular}

Source: Al-Khawaldeh (2013), Al-Asali and Suwaidan (2017), and Alwaely \& Alkhazalehb (2020)

Based on table (6), the degree to which the faculty members in Jordanian universities promote citizenship values among students is high. That is because the overall mean is 4.09 . The latter result isn't in agreement with the result reached by Al-Khawaldeh (2013). It was found that faculty members in Jordanian universities highly contribute to encouraging students to comply with laws. That is because the mean of statement (6) is 4.73 which is high and ranked first. The latter result indicates that faculty members realize that complying with laws shall lead 
to the development of the society in political, social and economic areas.

It was found that faculty members in Jordanian universities contribute highly to promoting knowledge about well-known figures who defended the country and sacrificed their lives. That is because the mean of statement (2) is 4.63 which is high and ranked second. The latter result indicates that faculty members in Jordanian universities realize that promoting such knowledge shall encourage students to defend their country from any military, cultural or economic threat.

The researcher found that faculty members encourage students to hold on to their customs and traditions. That is because the mean of statement (3) is 4.52 which is high. The latter result indicates that faculty members are highly aware about the role of preserving customs and traditions in preserving the national and cultural identities of citizens. The researcher found that faculty members promote positive attitudes towards local products. That is because the mean of statement (3) is 4.24 which is high. The latter result indicates that faculty members realize the significance of supporting local economic institutions in developing homeland.

10.3. Results and Discussion related to the second question:

Q.2. To what degree do student activities in Jordanian universities promote citizenship values among students? Table (7): The degree to which the student activities in Jordanian universities promote citizenship values among students

\begin{tabular}{|l|l|l|l|l|l|}
\hline No. & Statement & Mean & Std. & Level & Rank \\
\hline 1. & Student activities encourage students to defend their homeland & 4.28 & 0.42 & High & 7 \\
\hline 2. & $\begin{array}{l}\text { Student activities encourage students to engage in national events } \\
\text { and celebrations }\end{array}$ & 4.33 & 0.27 & High & 6 \\
\hline 3. & $\begin{array}{l}\text { Student activities promote knowledge about the history of } \\
\text { establishing the state }\end{array}$ & 2.20 & 0.38 & Low & 11 \\
\hline 4. & Student activities promote belonging and loyalty to homeland & 4.70 & 0.61 & High & 1 \\
\hline 5. & $\begin{array}{l}\text { Student activities promote awareness about the role of civil } \\
\text { society institutions in achieving social development }\end{array}$ & 4.67 & 0.59 & High & 2 \\
\hline 6. & $\begin{array}{l}\text { Student activities encourage students to engage in voluntarily } \\
\text { works }\end{array}$ & 4.09 & 0.15 & High & 9 \\
\hline 7. & $\begin{array}{l}\text { Student activities encourage students to show compliance with } \\
\text { laws }\end{array}$ & 4.35 & 0.40 & High & 5 \\
\hline 8. & $\begin{array}{l}\text { Student activities encourage students to participate in social } \\
\text { development programs }\end{array}$ & 4.49 & 0.68 & High & 4 \\
\hline 9. & Student activities encourage students to fight against violence & 4.56 & 0.52 & High & 3 \\
\hline 10. & $\begin{array}{l}\text { Student activities encourage students to participate in political } \\
\text { activities in society }\end{array}$ & 2.22 & 0.49 & Low & 12 \\
\hline 11. & $\begin{array}{l}\text { Student activities promote knowledge about the government's } \\
\text { effort in addressing Muslims-related issues }\end{array}$ & 4.17 & 0.73 & High & 8 \\
\hline 12. & $\begin{array}{l}\text { Student activities promote knowledge about the government's } \\
\text { social and economic achievements }\end{array}$ & 3.61 & 0.67 & Moderate & 10 \\
\hline & Overall & 3.972 & 0.492 & High & \\
\hline
\end{tabular}

Source: Al-Shaqran (2016) and Al-Asali and Suwaidan (2017)

Based on table (7), the degree to which the student activities in Jordanian universities promote citizenship values among students is high. That is because the overall mean is 3.97. The latter result is not in agreement with the result reached by Al-Shaqran (2016). The researcher found that student activities promote belonging and loyalty to homeland. That is because the mean of statement (4) is 4.70 which is high and ranked first. The latter result indicates that the ones responsible for arranging student activities in Jordanian universities are concerned in promoting positive attitudes and love towards homeland. For instance, arranging trips to the wonderful landmarks and natural places in homeland shall strengthen one's belonging and love to his country.

The researcher found that student activities encourage students to fight against violence. That is because the mean of statement (9) is 4.56 which is high. The latter result indicates that the ones responsible for arranging student activities believe that fighting against violence shall contribute to reducing the losses and damages caused from violence and crimes. Reducing such losses and damages shall enable the government to dedicate more funds for achieving development.

The researcher found that student activities encourage students to participate in social development programs. That is because the mean of statement (8) is 4.49 which is high. The latter result indicates that the ones responsible for arranging student activities believe that such participating in social development shall improve the social bonds between the members of the society and promote tolerance.

The researcher found that student activities in Jordanian universities play a minor role in encouraging students 
to participate in political activities in society. That is because the mean of statement (10) is 2.22 which is low and ranked last. The latter results may be attributed to the inadequate political awareness among the ones responsible for arranging student activities in Jordanian universities.

10.4. Results and Discussion related to the third question:

Q.3. To what degree do curricula in Jordanian universities promote citizenship values among students?

Table (8): The degree to which the curricula in Jordanian universities promote citizenship values among students

\begin{tabular}{|l|l|l|l|l|l|}
\hline No. & Statement & Mean & Std. & Level & Rank \\
\hline 1. & Curricula promote democracy & 4.69 & 0.17 & High & 5 \\
\hline 2. & $\begin{array}{l}\text { Curricula encourage students to show compliance with customs and } \\
\text { traditions }\end{array}$ & 4.82 & 0.26 & High & 3 \\
\hline 3. & Curricula promote knowledge about the government's achievements & 4.94 & 0.83 & High & 1 \\
\hline 4. & Curricula encourage students to maintain national security & 4.86 & 0.52 & High & 2 \\
\hline 5. & $\begin{array}{l}\text { Curricula encourage students to engage in national events and } \\
\text { celebrations. }\end{array}$ & 2.31 & 0.34 & Low & 11 \\
\hline 6. & $\begin{array}{l}\text { Curricula promote awareness about the significance of civil society } \\
\text { institutions in society }\end{array}$ & 4.57 & 0.75 & High & 7 \\
\hline 7. & Curricula encourage students to engage in voluntarily works & 2.29 & 0.59 & Low & 12 \\
\hline 8. & $\begin{array}{l}\text { Curricula promote knowledge among students about their rights, and } \\
\text { obligations as citizens }\end{array}$ & 4.77 & 0.49 & High & 4 \\
\hline 9. & $\begin{array}{l}\text { Curricula encourage students to address the problems faced by } \\
\text { society }\end{array}$ & 4.64 & 0.51 & High & 6 \\
\hline 10. & Curricula promote tolerance among students & 4.52 & 0.73 & High & 8 \\
\hline 11. & Curricula promote awareness about the significance of global peace & 4.18 & 0.64 & High & 10 \\
\hline 12. & Curricula promote loyalty and belonging among students & 4.30 & 0.13 & High & 9 \\
\hline & Overall & 4.240 & 0.496 & High & \\
\hline
\end{tabular}

Source: Al-Zboun et al. (2020) and Al-Asali and Suwaidan (2017)

Based on table (8), the degree to which the curricula in Jordanian universities promote citizenship values among students is high. That is because the overall mean is 4.24 . The latter result is in agreement with the result reached by Al-Zboun et al. (2020). The researcher found that curricula in Jordanian universities contribute highly to promoting knowledge about the government's achievements. That is because the mean of statement (3) is 4.94 which is high and ranked first. The latter result may be attributed to the belief of the developers of such curricula that promoting knowledge about the government's great achievement shall contribute to promoting love, belonging and loyalty towards homeland.

The researcher found that curricula promote knowledge among students about their rights, and obligations as citizens. That is because the mean of statement (8) is 4.77 which is high. The latter result indicates that curricula developers realize that promoting such knowledge shall make citizens more responsible and reduce the number of violations made against human rights in society.

The researcher found that curricula encourage students to maintain national security. That is because the mean of statement (4) is 4.86 which is high. The latter result indicates that curricula developers believe that each citizen is responsible for maintaining national security. It indicates that they are aware of the significance of national security in developing homeland. For instance, if the country is secure, foreign and local investors shall be encouraged to make investments.

The researcher found that curricula in Jordanian universities play a minor role in encouraging students to engage in voluntarily works. That is because the mean of statement (7) is 2.29 which is low and ranked last. The latter result may be attributed to the poor awareness of the developers of such curricula about the significance of voluntarily works in developing the society and improving the social bonds between the members of the society.

\section{Conclusion}

The researcher found that the degree to which Jordanian universities promote citizenship values among students is high in all the areas jointly and separately. The degree to which the faculty members in Jordanian universities promote citizenship values among students is high. For instance, those faculty members encourage students to maintain public facilities and properties. They encourage students to hold on to their customs and traditions. They promote positive attitudes towards local products.

The degree to which student activities in Jordanian universities promote citizenship values among students is high. Such activities encourage students to defend their homeland. They encourage students to engage in national events and celebrations. They encourage students to engage in voluntarily works and show compliance with laws. The degree to which curricula in Jordanian universities promote citizenship values among students is high. 
Curricula in Jordanian universities promote democracy and awareness about the significance of civil society institutions in society. They promote knowledge among students about their rights, and obligations as citizens. They encourage students to address the problems faced by society. They promote loyalty and belonging among students.

\section{Recommendations}

The researcher recommends:

- Conducting similar studies that aim to explore the impact of gender and type of university (public or private) on students' attitudes towards the role of universities in promoting citizenship values

- Providing faculty members in Jordanian universities with training courses about the significance of promoting citizenship values among students

- Engaging universities students in initiatives and programs that aim at promoting citizenship values among them.

\section{References}

Al-Amery, A. (2020). Attitudes of the students at the institutes of fine arts in Iraq towards implementing active learning strategies in Arabic language courses and the associated challenges. Journal of Education and Practice, 11(13), 73-81

Al-Asali, A. and Suwaidan, R. (2017). The Role of Palestinian Universities in Developing the Values of Citizenship among the Students" of An-Najah National University and Al-Istiqlal University as a Case Study". Alistiqlal Journal for Research. 3(1). https://dsr.alistiqlal.edu.ps/page-1731-ar.html, DOI: 10.36554/1796003-001-002

Al-Awamrah, A. and Al-Zboon, M. (2013). The role of public Jordanian universities for enhancing citizenship education and its relation to developing self-autonomy for students for educational sciences according to their point of view. Al-Najah University Journal for Research (Human Sciences), 28(1), p.187-218

Al-Jaser, A. (2019). The Role of EFL curriculum in Promoting Citizenship Values among High School Students from Supervisors' and Teachers' Perspectives. IUG Journal of Educational and Psychological Sciences. 27(2),1-25, https://journals.iugaza.edu.ps/index.php/IUGJEPS/article/view/5506

Al-Khawaldeh, T. (2013). The Role of Jordanian Faculty Members in Promoting Citizenship Values from Students' Perspectives. Dirasat: $\quad$ Educational $\quad$ Sciences. https://journals.ju.edu.jo/DirasatEdu/article/view/4571

Al-Shaqran, R. (2016). The contribution of student activities in promoting citizenship values among the students enrolled in Umm Al Qura University. Journal of Education Science, 24(2), http://search.shamaa.org/FullRecord?ID=119726

Alwaely, S. \& Alkhazalehb, M. (2020). The Role of Teaching Staff to Advocate for Global Citizenship Values among Students in Hashemite University. International Journal of Innovation, Creativity and Change. 11(4). $18-35$

Al-Zboun, N.; Al-Zboun, M.; and Al-Khawaldeh, H. (2020). The Role of National Culture Curriculum in Developing and boosting college students' Values of Citizenship. IUG Journal of Educational and Psychology Sciences. 28(1), 647-660.

Danju, I. \& Uzunboylu, H. (2016). A content analysis of citizenship education, Global Journal on Humanites \& Social Sciences. [Online]. 04, pp 167-173. Available from: http://sproc.org/ojs/index.php/pntsbs

Hoge, J. D. (2002). Character education, citizenship education, and the social studies. The Social Studies 93 (3): $103-108$.

Jbarah, S. (2018). A proposal vision to activate the role of the education collages at Taiz University to developing the values of citizenship among the students. Humanities and Educational Sciences Journal. Issue 4. P.26-61

Lin, A. (2013). Citizenship education in American schools and its role in developing civic engagement: a review of the research. Educational Review. 67(1), pp.35-63

Lister, I. (1998). Citizenship and citizenship education in Britain. In O. Ichilov (ed.), Citizen- ship and Citizenship Education in a Changing World (London: Woburn Press), 254-266.

McCowan, T. (2009). Rethinking citizenship education: A curriculum for participatory democracy: continuum studies in educational research. 1st edition. UK. Bloomsbury Publishing

Nie, N.; Junn, J. and Stehlik-Barry, K. (1996). Education and democraticship in America. Chicago: The University of Chicago Press

Putnam, R. D. ((1995). 'Tuning in, tuning out: the strange disappearance of Social capital in America'. PS: Political Science and Politics. 28. 664-83

Salehi, M., \& Farhang, A. (2019). On the adequacy of the experimental approach to construct validation: the case of advertising literacy. Heliyon, 5(5). Retrieved from: https://doi.org/10.1016/j.heliyon.2019.e01686

Scott, D. and Lawson, H. (2002). Citizenship education and the curriculum. $1^{\text {st }}$ edition. USA. Greenwood Publishing Group. 
Shin, E.; and Bednarz, S. (2018). Spatial citizenship education: Citizenship through geography, first edition. New York. USA. Routledge

Verba, S. Schlozman, K.L.; and Brady, H.E. (1995). Voice and equality: Civic voluntarism in American Politics. Cambridge, Mass: Harvard University Press.

Westheimer, J. and Kahne, J. (2004). What kind of citizen? The politics of educating for democracy. American Educational Research Journal 41 (2): 237-269. 